\title{
ANALISIS KANDUNGAN NUTRISI BUAH RENGGA (Amomum dealbatum Roxb)
}

\author{
Handa Muliasari ${ }^{*}$, Agus Dwi Ananto', Muhsinul Ihsan² \\ 1Prodi Farmasi, Fakultas Kedokteran, Universitas Mataram, email:*handamuliasari@unram.ac.id \\ 2Jurusan Tadris IPA Biologi,FTIK, Universitas Islam Negeri Mataram, muhsinulihsan@gmail.com
}

INFO ARTIKEL

RiwayatArtikel:

Diterima: 28- 05-2019

Disetujui: 09-08-2019

\section{Kata Kunci:}

Rengga

Nutrisi

analisis proksimat

Pulau Lombok

\section{A. LATAR BELAKANG}

Indonesia adalah salah satu negara agraris yang sangat terkenal akan tanaman, baik yang dapat dikonsumsi sebagai pangan maupun yang berkhasiat obat. Kekayaan Indonesia akan flora (tumbuhan) menempatkan Indonesia pada urutan kelima di dunia ${ }^{1}$. Pemanfaatan tumbuhan utamanya adalah sebagai bahan pangan untuk memenuhi sumber gizi yang dibutuhkan manusia. Menurut Peraturan Pemerintah RI nomor 28 tahun 2004, pangan adalah segala sesuatu yang berasal dari sumber hayati dan air, baik yang diolah maupun yang tidak diolah, yang diperuntukkan sebagai makanan atau minuman bagi konsumsi manusia ${ }^{2}$.

Pengetahuan mengenai jenis-jenis tanaman terutama tanaman lokal yang selain dapat digunakan sebagai bahan pangan maupun obat sangat penting, hal ini dikarenakan banyak sekali manfaat yang bisa kita dapatkan. Penggunaan tanaman obat sebagai salah satu bahan alami pengobatan yang sudah dipercaya sejak dulu yang dilakukan oleh nenek moyang. Salah satu tanaman yang dapat dikonsumsi dan berkhasiat obat yang masih sangat jarang digunakan dan dikaji lebih dalam adalah tanaman rengga (Amomum dealbatum Roxb).

Tanaman rengga (Amomum dealbatum Roxb) tergolong family Zingiberaceae. Tanaman ini merupakan tanaman khas Pulau Lombok yang masih jarang dimanfaatkan potensinya. Buah tanaman rengga biasa dikonsumsi oleh masyarakat setempat, namun kandungan nutrisinya belum dilaporkan. Selain itu, kandungan metabolit primer dan sekunder yang dimiliki oleh tanaman ini memungkinkan untuk dimanfaatkan sebagai tanaman yang berkhasiat sebagai obat.

Tanaman tradisional family Zingiberaceae diketahui memiliki potensi terapi dan kuliner3. Berdasarkan penelitian sebelumnya telah menunjukkan bahwa ekstrak tanaman family ini bertindak sebagai anthelmintik terhadap cestode, Raillietina echinobothrida4. Studi fitokimia yang pernah dilakukan terhadap tanaman ini 
mengungkapkan adanya kandungan seperti triterpenoids dan diterpenes5.

Analisis kandungan nutrisi dan potensi tanaman rengga sebagai tanaman obat belum dilaporkan. Informasi tersebut penting mengingat tanaman ini banyak tumbuh di Pulau Lombok dan sangat berpotensi sebagai pangan bernutrisi dan tanaman obat.

\section{B. METODE PENELITIAN}

Buah tanaman rengga dikoleksi dari hutan daerah Narmada, Kabupaten Lombok Barat, Nusa Tenggara Barat (NTB). Buah yang masih segar dipisahkan dari kulit buah kemudian dianalisis kandungan nutrisinya dengan analisis proksimat mengikuti prosedur Association of Official Analytical Chemist (AOAC) ${ }^{6}$. Analisis proksimat dilakukan di Laboratorium Nutrisi, Fakultas Peternakan Universitas Mataram.

Analisis proksimat yang dilakukan meliputi kadar air, kadar abu, kadar lemak, kadar protein, dan kadar karbohidrat.

\section{Kadar air}

Analisis kadar air dilakukan dengan menggunakan metode oven ${ }^{6}$. Prinsipnya dengan menguapkan molekul air bebas yang ada dalam sampel. Sampel ditimbang sampai didapat bobot konstan dengan asumsi semua air yang terkandung dalam sampel sudah diuapkan. Banyaknya air yang diuapkan merupakan selisih bobot sebelum dan sesudah pengeringan. Cawan yang akan digunakan dioven terlebih dahulu selama 30 menit pada suhu $100-105^{\circ} \mathrm{C}$. Cawan didinginkan dalam desikator untuk menghilangkan uap air dan ditimbang (A).

Sampel ditimbang sebanyak 2 g dalam cawan yang sudah dikeringkan (B) kemudian dioven pada suhu $100-105^{\circ} \mathrm{C}$ selama 6 jam. Sampel didinginkan dalam desikator selama 30 menit dan ditimbang (C). Tahap ini diulangi hingga dicapai bobot yang konstan. Penentuan kadar air dihitung dengan rumus sebagai berikut.

$$
\text { Kadar air }(\%)=\frac{\mathrm{B}-\mathrm{C}}{\mathrm{B}-\mathrm{A}} \times 100 \%
$$

Keterangan:

A: berat cawan kosong (g)

B: berat cawan+sampel awal (g)

C: berat cawan + sampel kering (g)

\section{Kadar abu}

Analisis kadar abu dilakukan menggunakan metode oven ${ }^{6}$. Prinsipnya adalah pembakaran bahan-bahan organik yang diuraikan menjadi air dan karbondioksida tetapi zat anorganik tidak terbakar. Zat anorganik ini disebut abu. Cawan yang akan digunakan dioven terlebih dahulu selama 30 menit pada suhu $100-105{ }^{\circ} \mathrm{C}$.
Cawan didinginkan dalam desikator untuk menghilangkan uap air dan ditimbang (A). Sampel ditimbang sebanyak $2 \mathrm{~g}$ dalam cawan yang sudah dikeringkan (B) kemudian dibakar di atas nyala pembakar sampai tidak berasap dan dilanjutkan dengan pengabuan di dalam tanur bersuhu 550$600{ }^{\circ} \mathrm{C}$ sampai pengabuan sempurna. Sampel yang sudah diabukan didinginkan dalam desikator dan ditimbang (C). Tahap pembakaran dalam tanur diulangi sampai didapat bobot yang konstan. Penentuan kadar abu dihitung dengan rumus sebagai berikut.

$$
\text { Kadar abu (\%) }=\frac{\mathrm{C}-\mathrm{A}}{\text { B- A }} \quad \times 100 \%
$$

Keterangan:

A: berat cawan kosong (g)

B: berat cawan+sampel awal $(\mathrm{g})$

C: berat cawan + sampel kering (g)

\section{Kadar lemak}

Analisis kadar lemak dilakukan dengan metode sokhlet ${ }^{6}$. Prinsipnya adalah lemak yang terdapat dalam sampel diekstrak dengan menggunakan pelarut non polar. Labu lemak yang akan digunakan dioven selama 30 menit pada suhu 100-105 ${ }^{\circ} \mathrm{C}$. Labu lemak didinginkan dalam desikator untuk menghilangkan uap air dan ditimbang (A). Sampel ditimbang sebanyak $2 \mathrm{~g}$ (B) kemudian dibungkus dengan kertas saring, ditutup dengan kapas bebas lemak dan dimasukkan ke dalam sokhlet yang telah dihubungkan dengan labu lemak.

Sampel sebelumnya telah dioven dan diketahui bobotnya. Pelarut heksan dituangkan sampai sampel terendam dan dilakukan refluks atau ektraksi selama 5- 6 jam atau sampai palarut lemak yang turun ke labu lemak berwarna jernih.

Pelarut lemak yang telah digunakan, disuling, dan ditampung. Ekstrak lemak yang ada dalam labu lemak dikeringkan dalam oven bersuhu $100-105{ }^{\circ} \mathrm{C}$ selama 1 jam. Labu lemak didinginkan dalam desikator dan ditimbang (C). Tahap pengeringan labu lemak diulangi sampai diperoleh bobot yang konstan.

Penentuan kadar lemak dihitung dengan rumus sebagai berikut.

$$
\text { Lemak total }(\%)=\frac{(\mathrm{C}-\mathrm{A}) \times 100 \%}{\mathrm{~B}}
$$

Keterangan:

A: Berat labu alas bulat kosong (g)

B: berat sampel ( $\mathrm{g}$ )

C: berat labu alas bulat dan lemak hasil ekstraksi (g)

\section{Kadar protein}

Analisis kadar protein dilakukan dengan metode kjeldahl6. Prinsipnya adalah oksidasi 
bahan-bahan berkarbon dan konversi nitrogen menjadi amonia oleh asam sulfat, selanjutnya amonia bereaksi dengan kelebihan asam membentuk amonium sulfat. Amonium sulfat yang terbentuk diuraikan dan larutan dijadikan basa dengan $\mathrm{NaOH}$. Amonia yang diuapkan akan diikat dengan asam borat. Nitrogen yang terkandung dalam larutan ditentukan jumlahnya dengan titrasi menggunakan larutan baku asam.

Sampel ditimbang sebanyak 0,1-0,5 g, dimasukkan ke dalam labu kjeldahl $100 \mathrm{~mL}$, ditambahkan dengan 1/4 buah tablet, kemudian didekstruksi sampai larutan menjadi hijau jernih dan $\mathrm{SO}_{2}$ hilang. Larutan dibiarkan dingin dan dipindahkan ke labu $50 \mathrm{~mL}$ dan diencerkan dengan akuades sampai tanda tera, dimasukkan ke dalam alat destilasi, ditambahkan dengan 5-10 $\mathrm{mL} \mathrm{NaOH}$ 30-33\% dan dilakukan destilasi. Destilat ditampung dalam larutan $10 \mathrm{ml}$ asam borat 3\% dan beberapa tetes indikator (larutan bromcresol green 0,1\% dan 29 larutan metil merah 0,1\% dalam alkohol 95\% secara terpisah dan dicampurkan antara $10 \mathrm{ml}$ bromcresol green dengan $2 \mathrm{~mL}$ metil merah) kemudian dititrasi dengan larutan $\mathrm{HCl}$ 0,02 N sampai larutan berubah warnanya menjadi merah muda. Penentuan kadar protein dihitung dengan rumus sebagai berikut.
Protein $(\%)=\frac{(\text { VA }- \text { VB }) \text { HCL } \times \text { N HCL x } 14,007 \times 6,25 \times 100 \%}{\text { W x } 1000}$

Keterangan:

VA: $\mathrm{ml} \mathrm{HCl} \mathrm{untuk} \mathrm{titrasi} \mathrm{sampel}$

VB: ml HCl untuk titrasi blanko

$\mathrm{N}$ : normalitas $\mathrm{HCl}$ standar yang digunakan

$\mathrm{W}$ : berat sampel $(\mathrm{g})$

Dimana, Kadar protein dinyatakan dalam satuan g/10o g sampel.

\section{Kadar karbohidrat}

Penentuan kadar karbohidrat dihitung menggunakan by difference ${ }^{7}$ dengan rumus sebagai berikut.

Karbohidrat $(\%)=100 \%-($ kadar air + kadar protein + kadar abu + kadar lemak)\%

\section{HASIL DAN PEMBAHASAN}

\section{Tanaman Rengga (Amomum dealbatum Roxb).}

Tanaman Rengga diperoleh di hutan Dusun Batu Asak, Desa Buwun Sejati, Kecamatan Narmada, Lombok Barat, NTB. Gambar tanaman dan buah Rengga dapat dilihat pada Gambar 1. Tanaman ini tersebar luas dan berbuah hamper sepanjang tahun.

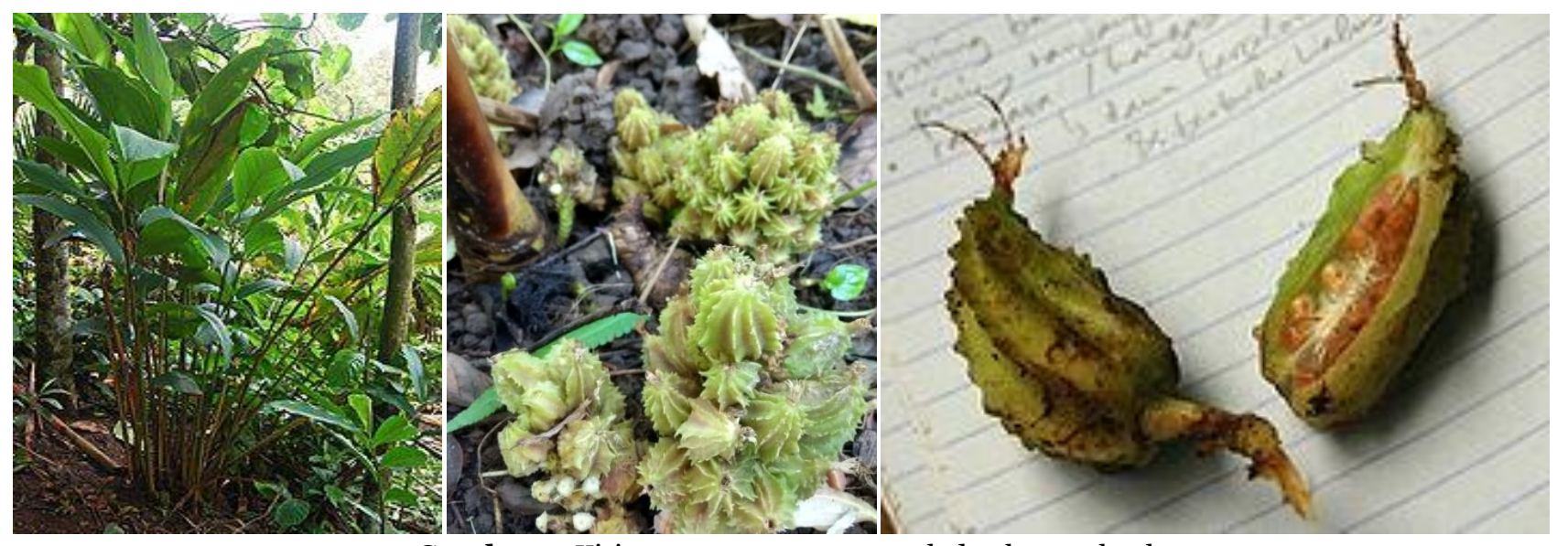

Gambar 1. Kiri: tanaman rengga, tengah dan kanan: buah rengga

Rengga di daerah lain di Indonesia biasa disebut Wresah atau Hanggasa. Sekilas, tekstur permukaan buah renggak memang aneh. Aroma buah ini menggoda, rasanya sedikit asam dan manis, buah mudanya dimakan setelah direbus. Tinggi pohonnya kira-kira seperti pohon laos. daun mirip dengan daun kunyit. Buah ini tumbuh di luar batang dekat akar. Pohon-pohon buah renggak banyak tumbuh di pinggir kali. Pohonnya juga hidup liar dan terpencar-pencar di hutan atau kebun, terutama pada tanah lembab yang kaya akan humus. Cara menanamnya cukup mengambil ujung rimpang yang berakar untuk ditanam ${ }^{8}$.
Rengga (Amomum dealbatum Roxb) memiliki nama sinonim Amomum maximum Roxb, namun di China keduanya dikatakan sebagai spesies yang berbeda. Tanaman rengga ditemukan di wilayah Asia seperti China, India, Thailand dan Indonesia. Buah rengga dapat dimakan secara langsung. Namun demikian, kandungan nutrisi, kandungan senyawa maupun bioaktivitasnya dalam pengobatan belum diketahui 9 .

Tanaman rengga termasuk dalam family Zingiberaceae. Family ini dikenal memiliki keragaman dan manfaat yang tinggi. Salah satu spesies yang dekat dengan tanaman rengga yaitu Amomum maximum, atau di Thailand dikenal 
dengan nama "Chi Kuk". Amomum maximum diketahui memiliki berbagai manfaat dalam pengobatan yaitu untuk mengobati batuk, flu, muntah-muntah, sakit kepala dan gangguan pencernaan. Buah dan bijinya digunakan untuk mengobati sakit perut ${ }^{10}$.

\section{Kandungan Nutrisi Buah Rengga}

Kandungan nutrisi dari buah rengga dapat dilihat pada Tabel 1. Adapun nutrisi buah rengga yang dapat dimakan (edible) yaitu bagian daging buah dan bijinya. Kandungan paling tinggi pada buah dan biji rengga sebagian besar adalah air (55.19 $\pm 0,27 \%)$ karena buah yang dianalisis adalah buah segar. Buah rengga memiliki kandungan

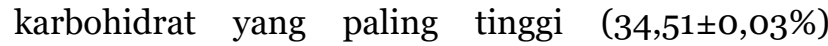
dibandingkan kandungan serat, lemak, dan protein. Data kandungan nutrisi buah rengga tersebut dibandingkan dengan kandungan nutrisi pada buah tanaman yang dekat dengan tanaman rengga yaitu Amomum maximum yang diteliti di Thailand ${ }^{11}$. Kandungan nutrisi pada tanaman Amomum maximum lebih rendah daripada buah rengga baik itu kandungan karbohidrat, lemak, serat, maupun protein.

TABEL 1

Kandungan nutrisi buah rengga

\begin{tabular}{ccc}
\hline $\begin{array}{c}\text { Kandungan } \\
\text { nutrisi (\%) }\end{array}$ & Rengga & $\begin{array}{c}\text { Amomum } \\
\text { maximu } \\
\text { m [10] }\end{array}$ \\
\hline Air & $55,19 \pm 0,27$ & $94,38 \pm 0,87$ \\
Abu & $3,72 \pm 0,10$ & $0,91 \pm 0,29$ \\
Lemak & $2,87 \pm 0,05$ & $0,61 \pm 0,12$ \\
Serat Protein & $6,46 \pm 0,57$ & $0,92 \pm 0,07$ \\
Karbohidrat & $3,13 \pm 0,09$ & $1,34 \pm 0,15$ \\
& $34,51 \pm 0,03$ & $1,84 \pm 0,13$ \\
\hline
\end{tabular}

Kandungan nutrisi yang paling penting adalah karbohidrat dan protein. Kandungan karbohidrat dan protein pada buah rengga cukup tinggi. Karbohidrat merupakan hasil alam yang memiliki banyak fungsi penting pada tanama, hewan, dan manusia. Karbohidrat disintesis oleh tanaman melalui reaksi fotosintesis, yaitu merubah karbon dioksida menjadi karbohidrat. Karbohidrat tersebut berada dalam bentuk selulosa, pati, dan gula-gula sakarida sederhana ${ }^{12}$.

Sebagian besar karbohidrat, terutama golongan monosakarida dan disakarida seperti glukosa, fruktosa, galaktosa, dan laktosa mempunyai sifat mereduksi. Sifat mereduksi dari karbohidrat disebabkan oleh adanya gugus aldehida atau gugus keton bebas dan gugus - $\mathrm{OH}$ bebas ${ }^{13}$.

Kadar karbohidrat diukur dengan menggunakan metode fenol sulfat. Prinsip dari metode ini adalah gula sederhana dan oligosakarida dapat bereaksi dengan fenol dalam asam sulfat pekat menghasilkan warna jingga kekuningan yang stabil. Dimana oligosakarida dihidrolisis menjadi monosakarida oleh asam sulfat pekat dan menghidrasinya sehingga membentuk senyawa furfural yang bereaksi dengan fenol menghasilkan warna jingga kekuningan. Penerapan metode fenol-sulfat banyak digunakan untuk menentukan karbohidrat dalam sampel secara langsung yang dinyatakan sebagai persen glukosa ${ }^{14}$.

Penelitian ini mengukur kadar karbohidrat buah dan biji rengga. Sebelum menganalisis sampel, terlebih dahulu melakukan ekstraksi sampel dengan menggunakan asam perklorat $52 \%$ yang dapat menghidrolisis pati dan melarutkan gula-gula yang ada pada sampel ${ }^{15}$. Setelah diperoleh ekstrak sampel, dilakukan pembuatan larutan standar glukosa dengan menambahkan larutan fenol $5 \%$ dan asam sulfat pekat. Warna larutan standar glukosa berubah dari tak berwarna menjadi warna jingga kekuningan. Hal ini terjadi karena asam sulfat pekat ketika direaksikan dengan fenol dan glukosa menghasilkan panas yang menyebabkan glukosa terhidrasi menjadi senyawa hidroksimetil furfural. Senyawa ini ketika bereaksi dengan fenol akan menghasilkan warna jingga kekuningan ${ }^{15}$.

Kandungan nutrisi yang penting lainnya adalah protein. Protein merupakan sumber asam amino yang mengandung unsur-unsur $\mathrm{C}, \mathrm{H}, \mathrm{O}$ dan $\mathrm{N}$ yang tidak dimiliki oleh lemak dan karbohidrat. Protein merupakan komponen yang banyak terdapat pada sel tanaman dan hewan. Kandungan protein dalam bahan pangan bervariasi baik dalam jumlah maupun jenisnya. Protein merupakan sumber gizi utama, yaitu sebagai sumber amino. Disamping berperan sebagai sumber gizi, protein dari sumber yang berbeda memiliki kekhasan sifat fungsional yang berpengaruh pada karakteristik produk pangan ${ }^{16}$.

Karena adanya kandungan unsur $\mathrm{N}$ maka penentuan jumlah protein dapat dilakukan dengan cara menentukan jumlah nitrogen $(\mathrm{N})$ yang ada dalam bahan pangan. Penentuan jumlah $\mathrm{N}$ total dilakukan untuk mewakili jumlah protein yang ada. Metode pengukuran kadar protein dengan prinsip tersebut adalah metode Kjeldahl. Pengukuran dengan metode Kjeldahl didasarkan atas pengukuran kandungan nitrogen total di dalam bahan pangan ${ }^{17}$.

Metode Kjeldahl terbagi atas tiga tahap, yaitu tahap dekstruksi, distilasi dan titrasi. Tahap dekstruksi terjadi penguraian sampel menjadi unsurunsurnya yaitu $\mathrm{H}, \mathrm{O}, \mathrm{N}$, dan $\mathrm{C}$ oleh asam sulfat pekat yang bersifat oksidator kuat. Elemen karbon (C), hidrogen $(\mathrm{H})$ akan teroksidasi menjadi $\mathrm{CO}_{2}, \mathrm{CO}$ dan $\mathrm{H}_{2} \mathrm{O}$, sedangkan nitrogen $(\mathrm{N})$ akan berubah menjadi $\left(\mathrm{NH}_{4}\right)_{2} \mathrm{SO}_{4}{ }^{18}$. Proses dekstruksi dibantu dengan adanya katalisator yang berfungsi untuk mempercepat kenaikan suhu asam sulfat yang berkisar pada suhu $370{ }^{\circ} \mathrm{C}-410{ }^{\circ} \mathrm{C}$, sehingga 
dekstruksi berjalan dengan cepat. Katalisator yang digunakan adalah campuran dari padatan $\mathrm{K}_{2} \mathrm{SO}_{4}$ dan $\mathrm{HgO}$, dimana $1 \mathrm{~g} \mathrm{~K}_{2} \mathrm{SO}_{4}$ dapat menanikkan titik didih $3{ }^{\circ} \mathrm{C}$. Proses ini dihentikan ketika larutan sampel menjadi jernih.

Tahap distilasi bertujuan untuk memisahkan zat yang diinginkan, yaitu memecah amonium sulfat $\left(\mathrm{NH}_{4}\right)_{2} \mathrm{SO}_{4}$ menjadi amonia $\left(\mathrm{NH}_{3}\right)$ dengan menambahkan $\mathrm{NaOH}$. Fungsi penambahan $\mathrm{NaOH}$ adalah untuk memberikan suasana basa, karena reaksi tidak dapat berlangsung asam. Uap amonia yang telah diperoleh dari pemecahan amonium sulfat ditangkap oleh larutan asam borat $\left(\mathrm{H}_{3} \mathrm{BO}_{3}\right)$ yang sebelumnya telah dicampur dengan indikator metil merah. Proses distilasi dihentikan ketika hasil destilat berwarna biru.

Tahap titrasi bertujuan untuk mengetahui berapa banyak asam borat bereaksi dengan amonia. Dimana hasil distilat ditrasi dengan $\mathrm{HCl}$. Larutan $\mathrm{HCl}$ akan mentitrasi amoniumborat menjadi amonium klorida sehingga pada akhir titrasi terjadi kelebihan $\mathrm{HCl}$. Akhir titrasi ditandai dengan perubahan larutan dari biru/hijau menjadi merah. Selain sampel, ada juga blanko yang melalui tiga tahap tersebut. Blanko berfungsi sebagai faktor koreksi terhadap senyawa $\mathrm{N}$ yang berasal dari pereaksi yang digunakan. Hasil titrasi yang diperoleh dapat mencari kadar nitrogen dan dikonversi ke protein dengan mengalikan kadar nitrogen dengan faktor konversi yaitu 6,25 yang diperoleh dari $100 / 16^{19}$. Unsur nitrogen adalah unsur utama protein, karna terdapat di dalam semua protein yang memiliki proporsi $16 \%$ dari total protein.

Kandungan metabolit sekunder tanaman rengga belum dilaporkan. Namun terdapat beberapa spesies pada genus yang sama (Amomum) yang dilaporkan memiliki kandungan senyawa dalam minyak atsiri. Minyak atsiri tanaman tersebut cukup tinggi. Beberapa senyawa yang terkandung dalam minyak atsiri tanaman Amomum maximum Roxb and Amomum muricarpum yang tumbuh di Vietnam. Minyak atsiri pada Amomum maximum Roxb terkandung senyawa-senyawa yaitu $\beta$-pinene (20,4$40,8 \%), \alpha$-pinene $(6,8-15,0 \%), \quad \beta$-elemene $\left(2,5^{-}\right.$ $12,8 \%)$ dan $\beta$-caryophyllene $(2,3-10,3 \%)$. Selain itu, $\beta$-phellandrene $(11,6 \%)$ ditemukan dalam minyak akar. Senyawa utama yang diidentifikasi dalam semua sampel minyak $A$. muricarpum adalah $\alpha-$ pinene (24,1-54,7\%) dan $\beta$-pinene (9,2-25,9\%). Sebagai tambahan, limonene $(7,4 \%)$ dan $d-3$-carene (9,4\%) masing-masing ditemukan dalam minyak daun dan minyak batang. Sementara $\beta$-phellandrene $(8,3 \%)$ banyak terdapat di minyak akar, buahbuahan mengandung sejumlah besar zingiberene (6,3\%). Kandungan terbesar yaitu t-muurolol (13,0\%) ditemukan dalam minyak bunga ${ }^{20}$.

\section{SIMPULAN DAN SARAN}

Kandungan nutrisi pada buah rengga yaitu kadar air 55,19 $\pm 0,27 \%$; kadar abu 3,72 $\pm 0,10 \%$; kadar karbohidrat $34,51 \pm 0,03 \%$; serat $6,46 \pm 0,57 \%$; lemak $2,87 \pm 0,05 \%$; dan protein $3,13 \pm 0,09 \%$.

\section{UCAPAN TERIMA KASIH}

Penulis mengucapkan terima kasih kepada Laboratorium Nutrisi Fakultas Peternakan Universitas Mataram yang telah membantu dan menyediakan fasilitas untuk penelitian ini.

\section{DAFTAR RUJUKAN}

1. Alamendah. (2012). Flora. Diunduh kembali dari http://alamendah.org/frolar/html

2. Lumba, R., "Kajian Pembuatan Beras Analog Berbasis Tepung Umbi Daluga (Crytosperma merkusii (Hassk) Schott), Jurnal Universitas Samratulangi, Vol. 5, No. 1, h. 1-13, 2012

3. Nguyen, TB., Flora of Vietnam, Science and Technology Publishing House, Hanoi, 2000

4. Chetia, M., Giri, B.R., Swargiary, A., Ronghang, B., Roy, B., "Amomum Maximum Roxb (Zingiberaceae), a “, Medicinal Plant of Tripura, India: a Natural Anthelmintic $J$ Adv Micros Res., Vol. 9, h. 148-153, 2014

5. Luo, J.G., Yin, Y., Fan, B.O., Kong, L.Y., "Labdane Diterpenoids from the Roots of Amomum Maximum and Their Cytotoxic Evaluation”, Helv Chim Acta., Vol. 97, h. 1140-1145, 2014

6. Association of Official Analytical Chemists (AOAC). Official Methods of Analysis, Association of Official Analytical Chemists, Washington, 2005

7. Winarno, F.G., Kimia Pangan dan Gizi, PT. Gramedia, Jakarta, 1986

8. Ken, F., Tropical Plants Database, $<$ tropical.theferns.info/viewtropical.php?id=Amomum $+\mathrm{d}$ ealbatum>, diakses 26 Juli 2019

9. Jansen, P.C.M., Jukema, J., Oyen, L.P.A., van Lingen, T.G.. Amomum dealbatum (PROSEA) Plant Resources of South-East Asia

10 Butsat, S., Siriamornpun, S., "Effect of Solvent Types and Extraction Times on Phenolic and Flavonoid Contents and Antioxidant Activity in Leaf Extracts of Amomum chinense C.", Int F ood Res , Vol. 23, h. 180-7, 2016

11. Rachkeeree, A., Kantadoung, K., Suksathan, R., Puangpradab, R., Alexander, P, Sommano, R.S., "Nutritional Compositions and Phytochemical Properties of the Edible Flowers from Selected Zingiberaceae Found in Thailand", Frontiers in Nutrition. doi: 10.3389/fnut.2018.00003, 2018

12. Setiyono, L., Pemanfaatan Biji Kurma (Phoenix dactylifera L.) Sebagai Tepung dan Analisis Perubahan Mutunya Selama Penyimpanan. Institut Teknologi Bogor Press, Bogor, 2011

13. Daud, M., "Biokonversi Bahan Berligno Selulosa Menjadi Bioetanol Menggunakan Aperligus niger dan Saccharomyces cerevisiae", Jurnal Perennial, Vol. 8, No. 2, h. 43-51, 2012

14. Amalia, A., Sartika, A., Review karbohidrat kelompok IV far. Diunduh kembali dari https://www.scribd.com/ doc/241025804/Review-KarbohidratKelompok-VI-Far$\mathrm{A} / \mathrm{html}, 2014$

15. Apriantono, A., Analisis Pangan, ITB Press, Bandung, 1988

16. Paramita, O., "Kajian Proses Pembuatan Tepung Buah Mangga (Mangifera indica L.) Varietas Arumanis dengan Suhu Perendaman yang Berbeda", Jurnal Bahan Terbarukan, Vol. 1, No. 1, h. 1-10, 2012 
17. Novika, C., "Kajian Penggunaan Tepung Millet Kuning Sebagai Subtitusi Tepung Terigu pada Karakteristik Sensoris, Fisikokimia dan Aktivitas Antioksidan Mi Instan Ubi Jalar Ungu", Jurnal Teknosains, Vol. 2, No. 1, h. 1-8, 2013

18. Sadli, Analisis Kandungan Karbohidrat, Lemak dan Protein dari Biji Durian (Durio zibethinus Murr) dengan Variasi Waktu Pengukusan. Universitas Tadulako, Palu, 2014

19. Bintang, M., Biokimia Teknik Penelitian. Erlangga, Jakarta, 2010

20. Huong, L.T., Dai, D. N., Thang, T. D., Bach, T. T., Ogunwande, I. A., "Volatile Constituents of Amomum maximum Roxb and Amomum microcarpum" in Liang, C. F. \& Fang, C. F., "Two Zingiberaceae Grown in Vietnam”, Natural Product Research, Vol. 29, No. 15, h. 1469-1472, http://dx.doi.org/10.1080/14786419.2014.1003064, 2015 